\title{
Impact of termite activity on soil environment: A perspective from their soluble chemical components
}

\author{
${ }^{1 *}$ K. Semhi; ${ }^{2}$ S. Chaudhuri; ${ }^{1}$ N. Clauer; ${ }^{3}$ J. L. Boeglin \\ ${ }^{1}$ Centre de Géochimie de la Surface (CNRS-ULP), Université Louis Pasteur, 1 rue Blessig, 67084 Strasbourg, France \\ ${ }^{2}$ Department of Geology, Kansas State University, Manhattan, Kansas 66506, USA \\ ${ }^{3}$ Laboratoire des Mécanismes et Transferts en Géologie (CNRS-IRD-OMP), Université Paul Sabatier, \\ 14 Avenue E. Belin, 31400 Toulouse, France \\ Received 18 April 2008; revised 12 May 2008; accepted 13 June 2008; available online 1 September 2008
}

\begin{abstract}
An investigation on varied types of termite mounds relative to the nearby soils that are not inhabited by the termites in different places of Cameroon show that the activity of the termites is increasing the contents of most major and some trace elements in the termite mounds, except for Si and sometimes Fe, Mn, Na and $\mathrm{K}$. These released elements are relocated into newly formed mineral phases that are dissolved by either $\mathrm{H}_{2} \mathrm{O}$ or dilute $\mathrm{HCl}$ leachings. The $\mathrm{Ca}$ and $\mathrm{Mn}$ released by the termite activity testify for crystallization of Ca-Mg carbonates and phosphates as well as of Fe oxy-hydroxides and/or Mn hydroxides. Termite activity also induces an increase in the lanthanide contents, the mound materials being especially enriched in light lanthanides relative to the corresponding soils without termite activity. The shapes of the patterns support precipitation of Mn-Fe oxy-hydroxides and Ca carbonates-phosphates. The increased amounts of Eu and Ce linked to termite activity seem to relate to the occurrence of reducing agents that are released by the termites, modifying $\mathrm{Eu}^{+3}$ into $\mathrm{Eu}^{+2}$ and $\mathrm{Ce}^{+4}$ into $\mathrm{Ce}^{+3}$, favoring in turn selective incorporation of $\mathrm{Eu}^{+2}$ and $\mathrm{Ce}^{3+}$ in the new phases of the termite mounds. Another consequence of the termite activity is the precipitation of $\mathrm{H}_{2} \mathrm{O}$ and $\mathrm{HCl}$ extractable phases having low $\mathrm{Sr} / \mathrm{Ca}$ ratios. Even if the $\mathrm{K} / \mathrm{Rb}$ values of the termite mounds are typical for common soil-forming silicate minerals, their relocation by an inorganic process alone does not explain an abnormally high ratio in the $\mathrm{H}_{2} \mathrm{O}$ leachable mineral phases. It was also shown that the main source for $\mathrm{K}$ and $\mathrm{Rb}$ of the dissolved phases is not only the interlayer site of clay particles, but also nutrients immobilized in and by the termites.
\end{abstract}

Key words: Trace elements, lanthanides, weathering, crystallization, ground and surface waters, termite activity

\section{INTRODUCTION}

Termites are common biological agents that produce significant physical and chemical modifications to tropical and subtropical soils (Nye, 1955; Sys, 1955; Pomeroy, 1976; Briese, 1982; Akamigbo, 1984; Lobry de Bruyn and Conacher, 1990 and 1995; Mando et al., 1996; Heikens et al., 2001). They generally go through a sequence of actions, from fetching, carrying to cementing mineral particles into mounds by using their salivary secretion (Howse, 1970; Wood, 1988; Donovan et al., 2001; Ndiaye et al., 2004; Vandecasteele et al., 2004; Lopez-Hernandez et al., 2006). For example, it has been shown that termite activity increases the content of organic matter in the soils that they use for the construction of their nests and also modifies the

\footnotetext{
ब *Corresponding Author Email:[УKP NKDG \DKRRTU

Tel./Fax: 0033631445071
}

clay mineral composition of these soil materials (Mahaney et al., 1999; Jouquet et al., 2002; Roose Amsaleg et al., 2004). Abundant literature can be found related to effects of termites on the mobility of a number of soil elements, but the focus is largely on those few elements that are generally considered to be essential for the support or growth of all forms of life (Jouquet et al., 2004; Brossard et al., 2007). The same literature has shown hardly any interest in examining the effect of termite activity on the mobility of trace elements that are generally considered to be nonessential to living systems. Nevertheless, it can not be altogether denied that the dynamics of mobility of trace elements may hold significant clues as to understandings of the processes of reorganization of soil minerals and relocation of chemical elements that 
constitute the frameworks of soil minerals. This report has made an attempt to depict characteristics of geochemical changes among several minor or trace elements, such as Rb, Sr, Th, U, Ar and the lanthanide group, in conjunction with major chemical and mineralogical changes, that may be produced in soil materials through termite activity. The lanthanide group consists in 14 elements ranging from La with atomic number 57 to $\mathrm{Lu}$ with atomic number 71 . Lanthanides and rare earth elements (REE) are synonymous words, the former term being used frequently by biologists and soil scientists, where the latter is used more popularly by geologists and geochemists.

It might be added that the results of this study cover only a limited geographical area with narrowly defined termite species and can not be applied universally to geochemical modifications produced in soils by termite activity, because termite species are widely varied with a wide range of living, breeding, and feeding habits.

However, it might be of interest to note that (1) termites generally built epigeous nests having homogenous structures, even if the nests have varied shapes, (2) the materials needed for the construction of the nests are taken by the termites from immediate environment, generally limited to a few meters surrounding the nested area, (3) the mineral particles of the soils represent often the basic used material, and (4) termites mix soil materials with wood and excrements for the construction of their nests (Noirot, 1970; Jungerius et al., 1999). In fact, the supply of fine clay particles is adequate for building the nests or mounds that are characterized by thick, dense and solid outer layers, protecting chambers and communicating passages of the mounds. It must be of interest that sponge-like mass of chewed wood fills most of the chambers together with fungus-like material. Because termite activity could have the potential of causing the development of newly-formed materials, this report also provides an account of the amorphous materials that may be derived from their activity.

\section{MATERIALS AND METHODS}

Materials

Four pairs of samples were collected in different localities of Cameroon (Ndma Ngoupayou, 1997) that are representative of varied environments in either natural sites away from any human activity, or in places where the natural environment was replaced by human agricultural activity. Each pair of samples represents a termite-affected material taken from a mound/nest (labelled conventionally termite "mound") and the corresponding soil sample taken several meters away from closest mound and considered to be the reference without significant termite activity (labelled conventionally "soil" without termites), not meaning necessarily that no termite activity never occurred in it. The sample pair 1 comes from southern Cameroon near a village called Nsimi; the mound being constructed on a tree stock, consisting in indurated, laminated material in a forested area, with a nearby sand-clay type soil at $3 \mathrm{~m}$. from mound. The sample pair 2 was collected next to a village named Dibamba, close to Douala; the mound being also constructed on a tree stock in a humid region close to the ocean were the original forest vegetation was replaced by a traditional agriculture without fertilizers on a yellowish sand. The sample pair 3 was taken at Yambassa near Ebebda in central Cameroon in an open grassy, savanna-type, region on a sandy clay rich soil. The sample pair 4 comes from Fomopea near Dschang in western Cameroon; the mound being constructed on a grassy slope at an altitude of $1500 \mathrm{~m}$. on a soil deriving from clay-rich sedimentary rocks.

\section{Methods}

The termite mounds were excavated and dismantled. Samples of about $2 \mathrm{~kg}$ which were thoroughly mixed by repeated (more than 10 times) conning and quartering. They were dried for 5 days at room temperature, and placed afterwards in an oven at $60^{\circ} \mathrm{C}$ for about $10 \mathrm{~h}$. before being crushed in a mortar and split into five aliquots. One fraction was analysed for the mineral composition by X-Ray diffraction (XRD). A second aliquot was first leached with double distilled,deionized $\mathrm{H}_{2} \mathrm{O}$ during $15 \mathrm{~min}$. for chemical analysis of the leachate, followed by a second leaching with $1 \mathrm{~N} \mathrm{HCl}$ again for $15 \mathrm{~min}$. at room temperature also for chemical analysis of the leachate. Another aliquot was used for extraction of the amorphous phases, and the remaining powder was taken for both major and trace element analysis and for K-Ar isotopic tracing.

\section{Extraction of the amorphous phases}

The amorphous phases of the termite mounds and soils without termites were extracted as following methods of Chao and Zhou (1983). The samples were first treated with Morgan's reagent, which consists of a $1 \mathrm{M}$ sodium acetate solution at $\mathrm{pH} 5$, to remove the 
exchangeable ions from mineral and organic components. Then, the Tamm reagent consisting of $16.1 \mathrm{~g} / \mathrm{L}$ ammonium oxalate and $10.9 \mathrm{~g} / \mathrm{L}$ of oxalic acid, was used to dissolve the amorphous components. The procedure consisted in a mixing of $40 \mathrm{~mL}$ of Morgan's reagent pro $g$ of soil shaken together for $4 \mathrm{~h}$. at room temperature $\left(25^{\circ} \mathrm{C}\right)$ in a polypropylene tube. Each sample was treated afterwards with $40 \mathrm{~mL}$ of Tamm's reagent in the dark at room temperature $\left(25^{\circ} \mathrm{C}\right)$.

\section{Laboratory analyses}

Chemical and mineralogical investigations were carried out on the bulk samples and the $<2 \mu \mathrm{m}$ size fractions of the mounds build by the termites and the corresponding soils without termites. The $<2 \mu \mathrm{m}$ fractions were separated from bulk samples of two sites by sedimentation in double-distilled water, followed by a centrifugation to concentrate the separated fractions. The mineralogy of both the bulk samples and the size fractions were analyzed by XRD. One XRD diagram of a disordered powder from bulk sample as well as three XRD diagrams of the $<2 \mu$ m oriented smear slides, (1) after drying at room temperature, (2) after glycol solvation and (3) after heating at $490{ }^{\circ} \mathrm{C}$ for $4 \mathrm{~h}$. were run.

Chemical analyses were performed on an ICP-AES (ARL $3500 \mathrm{C}$ ) for the major elements and some trace elements. Some trace elements were determined on an ICP-MS (VG Plasmaquad PQ2+) following a method described by Samuel et al. (1985). The analytical precisions are known to be at $5 \%$ for the major elements and at $10 \%$ for the trace elements (at the $2 \sigma$ level) by repetitive analysis of standard powders during the course of the study.

\section{RESULTS AND DISCUSSION}

The results are presented in successive sections that detail the data of the bulk samples and the $<2 \mu \mathrm{m}$ fractions of the termite mounds and soils without termites, and the $\mathrm{H}_{2} \mathrm{O}$ and dilute $\mathrm{HCl}$ extracts. The results are then followed by their discussion.

\section{Bulk samples}

The termite mounds consisted dominantly of clay minerals with quartz, whereas the corresponding soils without termites contained more quartz than clay minerals. Small amounts of Fe-oxi-hydroxides were present in both soils, but relatively more in the termite mounds.
The XRD analyses indicated that the clay minerals were essentially kaolinite with a minor amount of chlorite. The bulk samples consist mainly in $\mathrm{Si}, \mathrm{Al}$ and $\mathrm{Fe}$ and secondarily in $\mathrm{Mg}, \mathrm{Ca}, \mathrm{Na}, \mathrm{K}$, Ti and $\mathrm{Mn}$ (Table 1). A comparison of the materials from mounds 1,2 and 3 with the corresponding soils without termite activity reveals that termite activity apparently increased concentrations for a number of major elements, such as $\mathrm{Al}, \mathrm{Ca}, \mathrm{Mg}, \mathrm{K}$, and $\mathrm{Ti}$, but markedly decreased the concentrations of Si. Like many of the major elements, the concentrations of $\mathrm{Fe}$ and $\mathrm{Mn}$ in materials from mounds 1 and 2, but not in material from mound 3, were also found to have been increased relative to that in corresponding soils without termite activity. In mound 3 , the Fe concentration apparently remains unchanged and the $\mathrm{Mn}$ concentration rather decreases. The termite activity in mound 4 apparently produces no significant change in the bulk chemical compositions, unlike noticeable major chemical changes relative to the other three mounds.

In each case, the $\mathrm{Sr} / \mathrm{Ca}$ ratio of the material from termite mounds is lower than that of the corresponding soils without termite activity. The $\mathrm{Sr} / \mathrm{Ca}$ ratio for materials from mounds ranges from 7.5 to $174 \times 10^{-3}$ and that for the corresponding soils without termite activity from 98 to $245 \times 10^{-3}$, the decreases due to termite activity are because of relatively higher increases in $\mathrm{Ca}$ than in Sr (Table 1).

The $\mathrm{K} / \mathrm{Rb}$ ratio ranges from 127 to 401 for the materials from mounds and that for the corresponding soils without termite activity from 36.5 to 388 . The data for the materials from mound 1 and mound 2 relative to the data for the corresponding soils without termite activity suggest that termite activity in these two cases increases the $\mathrm{K} / \mathrm{Rb}$ ratio, the increases in the $\mathrm{K} / \mathrm{Rb}$ ratio for each being more due to an increase in the $\mathrm{K}$ concentration than an increase in the $\mathrm{Rb}$ concentration. The $\mathrm{K} / \mathrm{Rb}$ ratio appears not to be affected by termite activity in the other two cases, where the ratio in each instance remains unchanged, although both $\mathrm{K}$ and $\mathrm{Rb}$ concentrations increase for the material from mound 3 , whereas they remain unchanged for the material from mound 4 , relative to the concentrations of the corresponding soil materials.

The K-Ar isotope analyses indicate that the K-Ar dates for the samples from three termite mounds (1, 3 and 4) to be lower than that for the corresponding soils without termite activity: $652 \mathrm{Ma}$ for the material from mound 1 versus $886 \mathrm{Ma}$ for the corresponding soil 
without termite activity, $486 \mathrm{Ma}$ for that from mound 3 versus $615 \mathrm{Ma}$ for the corresponding soil without termite activity, and $368 \mathrm{Ma}$ for that from mound 4 versus $403 \mathrm{Ma}$ for the corresponding soil without termite activity (Table 1). The differentials in the dates were not related to the same factors for all three sets of samples. Termite activity apparently induces decreases in the content of radiogenic ${ }^{40} \mathrm{Ar}$ for the samples of two termite mounds ( 1 and 4), but an increase in the $\mathrm{K}$ content for the material from mound 3 and no change in the $\mathrm{K}$ concentration for the material from mound 4, relative to their corresponding samples without termite activity (Table 1). By contrast, the materials related to mound 3 show increases in both ${ }^{40} \mathrm{Ar}$ and $\mathrm{K}$ concentrations.

The total lanthanide concentrations (i.e., the sum of concentrations of $\mathrm{La}, \mathrm{Ce}, \mathrm{Pr}, \mathrm{Nd}, \mathrm{Sm}, \mathrm{Eu}, \mathrm{Gd}, \mathrm{Tb}, \mathrm{Dy}$, $\mathrm{Ho}, \mathrm{Er}, \mathrm{Tm}, \mathrm{Yb}$ and $\mathrm{Lu}$ ) for three of the four mounds, namely mounds 1, 2 and 4, are relatively higher than the corresponding soil samples without termite activity; the sample from the remaining mound 3 has a lower total lanthanide concentration than the corresponding soil without termite activity (Table 1). The total lanthanide concentration ranges from 142 to $329 \mu \mathrm{g} / \mathrm{g}$ for the termite mounds and ranges from 92 to $536 \mu \mathrm{g} / \mathrm{g}$ for the corresponding soils without termite activity.

The post archean Australian shale (PAAS), (McLennan, 1989) normalized relative to the distribution of the lanthanides for each of the mound sample and soil sample without termite activity are characterised by downward concave patterns with enrichment of the middle lanthanides from Eu to Er, but with varied degrees of $\mathrm{Ce}$ and $\mathrm{Eu}$ anomalies, some being not significant at analytical uncertainty. Considering the PAAS-normalized relative distribution patterns, the sample from mound 1 and the corresponding soil without termite activity have negative $\mathrm{Ce}$ anomalies, but no Eu anomaly. The sample from mound 2 has both $\mathrm{Ce}$ and Eu positive anomalies, but the corresponding soil sample without termite activity has neither a $\mathrm{Ce}$ anomaly, nor an Eu anomaly. The sample from mound 3 outlines only an Eu positive anomaly and the corresponding soil without termite activity has a $\mathrm{Ce}$ negative anomaly as well as a positive Eu anomaly. The sample from mound 4 and the corresponding soil sample both have a Eu positive anomaly (Fig. 1a). The distribution patterns of the lanthanides of the samples from the four mounds with the values normalized to the lanthanide values of the corresponding soils without termite activity are shown in Fig. 1b. This comparative basis provides three distribution patterns for the samples from different mounds. The sample from mound 1 has a light REE enrichment (which can, in another way, be described as a heavy REE depletion) distribution pattern, whereas the samples from mound 2 and mound 4 both have almost flat lanthanide distribution patterns, but with a marked negative $\mathrm{Eu}$ anomaly for the sample from mound 2. By contrast, the sample from mound 3 has, broadly speaking, a concave upward lanthanide distribution pattern with a marked negative Gd anomaly.

\section{Amorphous materials}

The amounts of amorphous materials in the samples from mounds and in the corresponding soils without termite activity are presented in Table 2 . The amounts from mounds range from 0.06 to $10.8 \mathrm{mg} / \mathrm{g}$, whereas those from soils without termite activity range from 0.04 to $10.7 \mathrm{mg} / \mathrm{g}$. Only a significant difference in the amount of amorphous material exists between the material of mound 2 with a value of about $0.5 \mathrm{mg} / \mathrm{g}$ and the corresponding soil without termite activity with a value of $0.04 \mathrm{mg} / \mathrm{g}$. This relatively higher value for the mound 2 material is an effect of an increase in $\mathrm{Al}$ in conjunction with decrease in Si. The differences in the amounts of amorphous materials for the other three cases were relatively quite small. Nevertheless, there are relative decreases in $\mathrm{Si}$ concentrations and increases in $\mathrm{Al}$ concentrations for materials from three mounds (namely mound 1,2 and 3), when compared to the concentrations of the same elements for the corresponding soil materials without termite activity.

\section{Clay fractions}

The clay fraction (less than 2 micrometers in diameter) of the material from termite mounds yields higher concentrations of $\mathrm{Ca}, \mathrm{Sr}, \mathrm{Na}, \mathrm{K}, \mathrm{Fe}$ and $\mathrm{P}$, but with about no changes in $\mathrm{Si}, \mathrm{Al}, \mathrm{Ti}$ and $\mathrm{Rb}$ concentrations (Table 3 ). Termite activity appears to have increased the $\mathrm{K} / \mathrm{Rb}$ ratio, as the clay fractions of the soils without termite activity have a $\mathrm{K} / \mathrm{Rb}$ ratio of about 198 in contrast to the clay fraction of the mounds with a ratio of about 282 . The $\mathrm{Sr} / \mathrm{Ca}$ ratio decreases from $57 \times 10^{-3}$ for the clay fraction from the soils without termite activity to $11 \times 10^{-3}$ for the clay fraction of the material from mounds. This decrease results from a greater increase in the $\mathrm{Ca}$ concentration than in the $\mathrm{Sr}$ concentration. The total lanthanide concentration of 
Int. J. Environ. Sci. Tech., 5 (4), 431-444, Autumn 2008

Table 1: Chemical composition of the termite mounds (labelled TM) and the corresponding soils without termites (labelled SWT) in major, trace and rare-earth elements

\begin{tabular}{|c|c|c|c|c|c|c|c|c|}
\hline \multirow[t]{2}{*}{ Major (mg/g) } & \multicolumn{2}{|c|}{ Sample pair 1} & \multicolumn{2}{|c|}{ Sample pair 2} & \multicolumn{2}{|c|}{ Sample pair 3} & \multicolumn{2}{|c|}{ Sample pair 4} \\
\hline & TM & SWT & TM & SWT & TM & SWT & TM & SWT \\
\hline$\overline{\mathrm{Si}}$ & 289.1 & 334.4 & 194.4 & 372.5 & 341.4 & 387.5 & 292.4 & 317.0 \\
\hline $\mathrm{Al}$ & 143.3 & 115.3 & 130.4 & 66.7 & 83.9 & 67.2 & 119.7 & 107.2 \\
\hline $\mathrm{Mg}$ & 3.43 & 1.08 & 22.8 & 0.46 & 1.95 & 1.24 & 3.55 & 3.00 \\
\hline $\mathrm{Ca}$ & 9.82 & 0.24 & 131.3 & 0.23 & 1.46 & 0.78 & 0.65 & 0.55 \\
\hline $\mathrm{Fe}$ & 51.8 & 41.9 & 53.0 & 26.6 & 31.7 & 31.9 & 61.0 & 56.5 \\
\hline $\mathrm{Mn}$ & 0.90 & 0.18 & 4.55 & 0.10 & 0.76 & 2.87 & 0.39 & 0.32 \\
\hline $\mathrm{Ti}$ & 9.01 & 7.92 & 11.4 & 10.23 & 7.18 & 4.17 & 7.06 & 5.91 \\
\hline $\mathrm{Na}$ & 0.16 & 0.17 & 1.41 & 0.08 & 1.76 & 1.37 & 0.59 & 0.74 \\
\hline K & 3.69 & 2.16 & 28.3 & 0.54 & 28.6 & 19.5 & 20.0 & 22.3 \\
\hline $\mathrm{P}$ & 1.11 & 0.59 & 17.37 & 1.66 & 0.33 & 0.14 & 0.49 & 0.43 \\
\hline Total & 512.4 & 503.9 & 595.0 & 479.2 & 499.0 & 516.7 & 505.8 & 514.0 \\
\hline $\mathrm{Sr} / \mathrm{Ca}\left(10^{-3}\right)$ & 11.9 & 97.9 & 7.51 & 212.5 & 92,3 & 129.4 & 174.0 & 245,4 \\
\hline $\mathrm{K} / \mathrm{Rb}$ & 126.7 & 103.6 & 223.2 & 36.49 & 400.6 & 388.1 & 181.1 & 208.4 \\
\hline $\operatorname{Ar}(\%)$ & 16.9 & 2.8 & ND & ND & 83.6 & 88.6 & 79.4 & 85.4 \\
\hline${ }^{40} \mathrm{Ar}\left(10^{-6} \mathrm{~cm}^{3} / \mathrm{g}\right)$ & 6.58 & 16.90 & ND & ND & 62.62 & 53.18 & 32.33 & 38.96 \\
\hline $\mathrm{K}-\mathrm{Ar}(\mathrm{Ma} \pm 2 \sigma)$ & $652(31)$ & $886(41)$ & ND & ND & $486(14)$ & $615(22)$ & $368(13)$ & 404 (13) \\
\hline \multicolumn{9}{|l|}{ Trace $(\mu \mathrm{g} / \mathrm{g})$} \\
\hline $\mathrm{Sr}$ & 116.3 & 23.7 & 984.9 & 48.9 & 134.7 & 100.9 & 113.1 & 135.0 \\
\hline $\mathrm{Ba}$ & 122.7 & 83.5 & bdl & 96.7 & 2340 & 1941 & 756.5 & 880.7 \\
\hline V & 133.2 & 109.5 & 189.4 & 109.7 & 78.7 & 83.0 & 162.8 & 150.5 \\
\hline $\mathrm{Ni}$ & 63.4 & 47.4 & bdl & 15.2 & 12.9 & 9.46 & 23.8 & 21.0 \\
\hline $\mathrm{Co}$ & 19.0 & 13.5 & bdl & bdl & 8.62 & 18.9 & 13.6 & 13.3 \\
\hline $\mathrm{Cr}$ & 152.3 & 136.6 & 132.6 & 91.2 & 28.0 & 27.3 & 40.7 & 38.7 \\
\hline $\mathrm{Zn}$ & 80.4 & 58.7 & bdl & 31.5 & 42.0 & 30.5 & 64.5 & 58.6 \\
\hline $\mathrm{Cu}$ & 50.8 & 24.8 & 208.3 & 10.9 & 14.0 & 11.6 & 29.4 & 31.0 \\
\hline $\mathrm{Zr}$ & 526.5 & 584.6 & 681.8 & 693.0 & 2259 & 1287 & 424.1 & 351.9 \\
\hline $\mathrm{Rb}$ & 29.1 & 20.9 & 126.8 & 14.8 & 68.9 & 48.6 & 110.4 & 107.1 \\
\hline $\mathrm{Pb}$ & ND & ND & 6.01 & 24.1 & 34.0 & 114.1 & 32.4 & 32.8 \\
\hline $\mathrm{Th}$ & 19.6 & 15.2 & 27.2 & 17.9 & 12.1 & 7.49 & 35.9 & 29.7 \\
\hline $\mathrm{U}$ & 2.89 & 2.53 & 3.67 & 2.17 & 2.62 & 1.69 & 9.81 & 8.6 \\
\hline $\mathrm{U} / \mathrm{Th}$ & 0.15 & 0.17 & 0.14 & 0.12 & 0.22 & 0.23 & 0.27 & 0.29 \\
\hline \multicolumn{9}{|l|}{$\operatorname{REE}(\mu \mathrm{g} / \mathrm{g})$} \\
\hline $\mathrm{La}$ & 33.5 & 23.3 & 79.4 & 44.8 & 41.7 & 26.6 & 42.1 & 35.2 \\
\hline $\mathrm{Ce}$ & 68.4 & 41.0 & 141.0 & 98.5 & 120.5 & 473.3 & 119.4 & 109.2 \\
\hline $\operatorname{Pr}$ & 6.09 & 4.02 & 16.5 & 9.46 & 7.42 & 5.21 & 9.84 & 8.41 \\
\hline $\mathrm{Nd}$ & 20.4 & 13.4 & 60.8 & 34.5 & 26.0 & 17.7 & 36.8 & 31.8 \\
\hline $\mathrm{Sm}$ & 3.41 & 2.26 & 11.0 & 6.19 & 3.74 & 2.71 & 6.92 & 5.98 \\
\hline $\mathrm{Eu}$ & 0.70 & 0.51 & 2.31 & 1.24 & 1.17 & 0.92 & 1.60 & 1.44 \\
\hline Gd & 2.48 & 1.84 & 7.32 & 4.12 & 3.14 & 4.02 & 4.99 & 4.39 \\
\hline $\mathrm{Tb}$ & 0.41 & 0.31 & 0.96 & 0.55 & 0.41 & 0.34 & 0.72 & 0.63 \\
\hline Dy & 2.31 & 1.81 & 4.48 & 2.51 & 2.44 & 1.65 & 3.58 & 3.26 \\
\hline Ho & 0.52 & 0.42 & 0.84 & 0.45 & 0.57 & 0.38 & 0.73 & 0.65 \\
\hline Er & 1.38 & 1.11 & 2.16 & 1.22 & 1.81 & 1.17 & 1.97 & 1.76 \\
\hline $\mathrm{Tm}$ & 0.23 & 0.19 & 0.33 & 0.20 & 0.35 & 0.22 & 0.31 & 0.29 \\
\hline $\mathrm{Yb}$ & 1.55 & 1.37 & 2.20 & 1.34 & 2.71 & 1.73 & 2.10 & 1.95 \\
\hline $\mathrm{Lu}$ & 0.25 & 0.23 & 0.37 & 0.23 & 0.57 & 0.35 & 0.36 & 0.33 \\
\hline Total & 141.6 & 91.6 & 329.4 & 205.3 & 212.5 & 536.3 & 231.4 & 205.3 \\
\hline $\mathrm{Ce} / \mathrm{Ce}^{*}$ & 0.78 & 0.54 & 1.98 & 1.12 & 0.98 & 0.64 & 1.09 & 0.93 \\
\hline $\mathrm{Eu} / \mathrm{Eu}^{*}$ & 1.13 & 1.18 & 1.20 & 1.15 & 1.61 & 1.26 & 1.28 & 1.32 \\
\hline
\end{tabular}

$\mathrm{bdl}=$ below detection limit; ND $=$ Not Detectable 

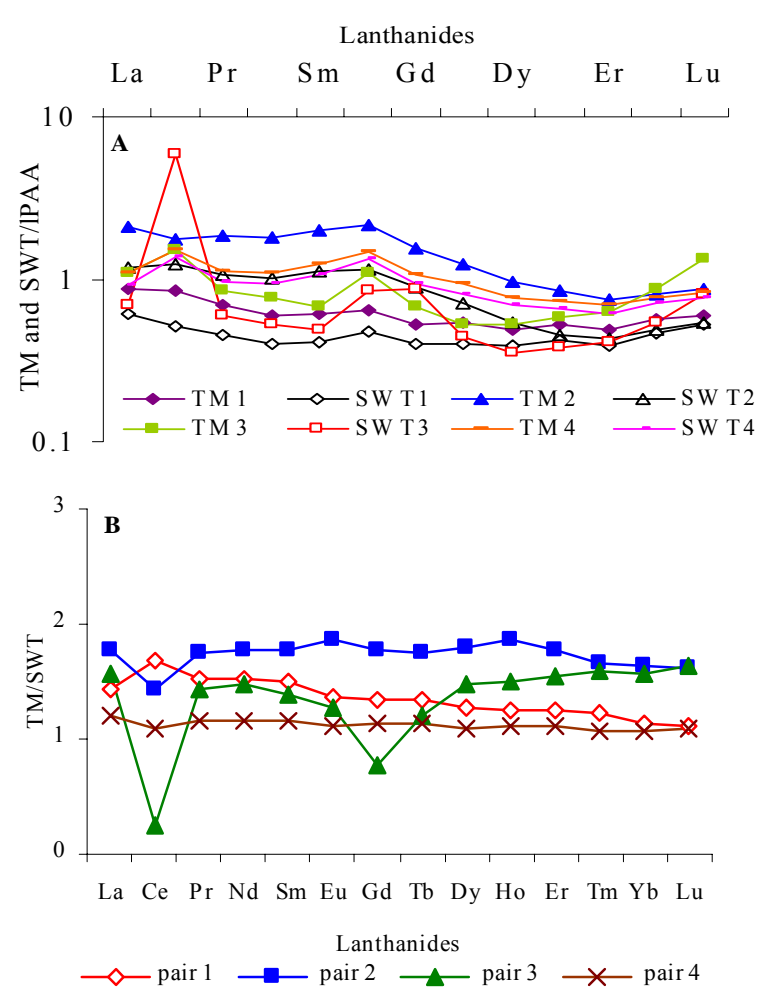

Fig. 1: Concentrations of the lanthanides in the sample pairs normalised (A) to the lanthanides in the Post Archean Australian Shales (PAAS) and (B) of the lanthanides from termite mounds normalysed to those in the soils without termites. TM stands for termite mounds and SWT for soils without termites

the clay fraction of the material from mounds is about $99 \mu \mathrm{g} / \mathrm{g}$, whereas that of the clay fraction from the corresponding soils without termite activity is about $113 \mu \mathrm{g} / \mathrm{g}$. Within the limits of the analytical error, the two values can be seen as being nearly identical. The distribution of the clay lanthanides from mounds normalized to the lanthanides of the soils without termites may be described by an enrichment in light lanthanides relative to heavy lanthanides with a slight positive Eu anomaly (Fig. 2).

\section{$\mathrm{H}_{2} \mathrm{O}$ and $\mathrm{HCl}$ extracts}

As already mentioned, the total dissolved constituents of the $\mathrm{H}_{2} \mathrm{O}$ extracts represent mainly the elements that were adsorbed on the mineral particles and organic compounds. For the termite mounds, they range from 0.09 to $15.1 \mathrm{mg} / \mathrm{g}$ and for the soil without termites from 0.06 to $0.07 \mathrm{mg} / \mathrm{g}$ (Table 4). The $\mathrm{K}$ and $\mathrm{Ca}$ contents collectively contribute to more than $27 \%$ of

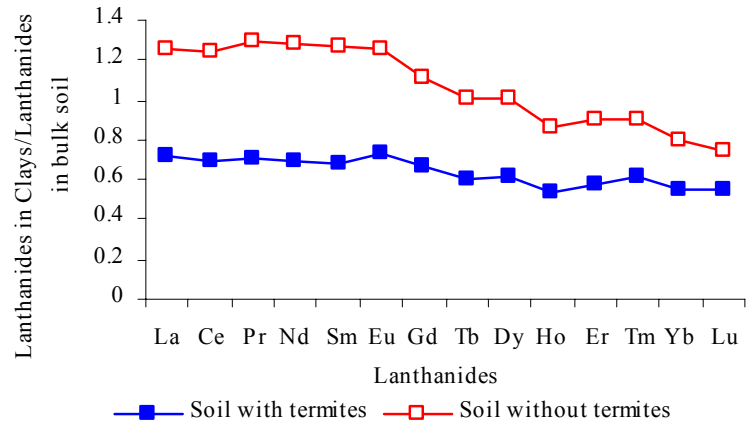

Fig. 2: Concentrations in lanthanides of the $<2 \mu \mathrm{m}$ clay fractions normalized to the concentrations of the corresponding termite mounds and soils without termites called bulks

the total dissolved constituents of the $\mathrm{H}_{2} \mathrm{O}$ extracts from termite mounds, and the $\mathrm{Si}, \mathrm{Al}$ and $\mathrm{Mg}$ each contribute about 3 to $30 \%$ of the total value. In contrast, the total dissolved constituents of the $\mathrm{H}_{2} \mathrm{O}$ extracts from soils without termites are largely dominated by $\mathrm{Si}, \mathrm{Al}$ and $\mathrm{K}$, collectively representing nearly $23 \%$ of the total dissolved amount in most samples. The $\mathrm{H}_{2} \mathrm{O}$ extract from termite mounds has a $\mathrm{K} / \mathrm{Rb}$ ratio of 184 to 1040 in contrast to that of the $\mathrm{H}_{2} \mathrm{O}$ extracts from soils without termite that varies narrowly from 120 to 161. A measurable difference exists also in the $\mathrm{Sr} / \mathrm{Ca}$ ratio from $\mathrm{H}_{2} \mathrm{O}$ extracts: that from mounds is of 4.2 to $11.1 \times 10^{-3}$ and that from soils without termites of 8.6 to $13.5 \times 10^{-3}$.

The general trend of the major element concentrations in the $\mathrm{H}_{2} \mathrm{O}$ leachates from all mounds but mound 3 is an increase, while being depleted in $\mathrm{Mn}, \mathrm{Al}, \mathrm{Fe}$, and $\mathrm{Ti}$, and remaining unchanged in $\mathrm{Si}$ concentrations. The $\mathrm{H}_{2} \mathrm{O}$ leachate of the mound 1 is depleted in $\mathrm{Ti}$ and $\mathrm{Na}$ and that of the mound 4 is enriched in all elements, except in $\mathrm{Mg}$.

The $\mathrm{HCl}$ extracts contain the elements released from soils subsequent to $\mathrm{H}_{2} \mathrm{O}$ leaching. They represent the components of the mineral and organic phases that were dissolved by the dilute $\mathrm{HCl}$. Those of the termite mounds yield a total dissolved constituent of 0.96 to $133 \mathrm{mg} / \mathrm{g}$ of soil, whereas those of the soils without termites have a significantly lower total dissolved constituent of 0.38 to $1.02 \mathrm{mg} / \mathrm{g}$ of soil (Table 5). Ca represents more than $30 \%$ of the total dissolved constituents of the $\mathrm{HCl}$ extracts from mounds, $\mathrm{Mg}$ about 10 to $20 \%$, and $\mathrm{K}$ about 8 to $24 \%$. By contrast, the total dissolved constituents from soil without termites consist mainly in Fe from 5 to $62 \%, \mathrm{Al}$ from 6 
Int. J. Environ. Sci. Tech., 5 (4), 431-444, Autumn 2008

Table 2: Chemical composition of the extracted amorphous phases

\begin{tabular}{|c|c|c|c|c|c|c|c|c|}
\hline Elements $^{*}$ & \multicolumn{2}{|c|}{ Sample pair 1} & \multicolumn{2}{|c|}{ Sample pair 2} & \multicolumn{2}{|c|}{ Sample pair 3} & \multicolumn{2}{|c|}{ Sample pair 4} \\
\hline $\mathrm{Si}$ & 751 & 1222 & 136.4 & 5.38 & 14.1 & 7.52 & 20.6 & 8.49 \\
\hline $\mathrm{Fe}$ & 5467 & 5170 & bdl & 0.04 & bdl & bdl & 0.07 & 0.04 \\
\hline $\mathrm{Mn}$ & 135 & 16.9 & 18.6 & 0.17 & 8.59 & 25.2 & 2.23 & 2.41 \\
\hline
\end{tabular}

$\mathrm{TM}=$ termite mounds, $\mathrm{SWT}=$ soils without termites, $\mathrm{bdl}=$ below detection limit;

"The concentrations are in $\mu \mathrm{g} / \mathrm{g}$

Table 3: Chemical composition of the $<2 \mu$ m clay fractions

\begin{tabular}{|c|c|c|}
\hline Elements ${ }^{*}$ & $\begin{array}{l}\text { Clays of termite } \\
\text { mounds }\end{array}$ & $\begin{array}{c}\text { Clays of soils } \\
\text { without termites }\end{array}$ \\
\hline $\mathrm{Si}$ & 219.9 & 224.9 \\
\hline $\mathrm{Al}$ & 104.0 & 103.1 \\
\hline $\mathrm{Mg}$ & 3.10 & 2.04 \\
\hline $\mathrm{Ca}$ & 3.90 & 0.52 \\
\hline $\mathrm{Fe}$ & 63.1 & 72.2 \\
\hline Mn & 0.46 & 0.22 \\
\hline $\mathrm{Ti}$ & 9.48 & 9.61 \\
\hline $\mathrm{Na}$ & 0.33 & 0.09 \\
\hline K & 7.76 & 5.69 \\
\hline$P$ & 1.29 & 0.74 \\
\hline $\mathrm{Rb}$ & 27.6 & 28.6 \\
\hline $\mathrm{Sr}$ & 45.0 & 30.0 \\
\hline $\mathrm{Sr} / \mathrm{Ca}$ & $11\left(10^{-3}\right)$ & $57\left(10^{-3}\right)$ \\
\hline $\mathrm{K} / \mathrm{Rb}$ & 282 & 198 \\
\hline $\mathrm{La}$ & 24.2 & 29.4 \\
\hline $\mathrm{Ce}$ & 47.6 & 50.7 \\
\hline $\operatorname{Pr}$ & 4.29 & 5.23 \\
\hline $\mathrm{Nd}$ & 14.2 & 17.2 \\
\hline $\mathrm{Sm}$ & 2.31 & 2.87 \\
\hline $\mathrm{Eu}$ & 0.51 & 0.64 \\
\hline Gd & 1.65 & 2.05 \\
\hline $\mathrm{Tb}$ & 0.25 & 0.31 \\
\hline Dy & 1.43 & 1.83 \\
\hline Ho & 0.28 & 0.36 \\
\hline $\mathrm{Er}$ & 0.8 & 1.01 \\
\hline $\operatorname{Tm}$ & 0.14 & 0.17 \\
\hline $\mathrm{Yb}$ & 0.86 & 1.09 \\
\hline $\mathrm{Lu}$ & 0.14 & 0.17 \\
\hline Total & 98.6 & 112.9 \\
\hline
\end{tabular}

to $61 \%$, and $\mathrm{Ca}$ from 5 to $38 \%$. The $\mathrm{K} / \mathrm{Rb}$ ratio of the $\mathrm{HCl}$ extracts from mounds ranges from 13 to 320 and that from the soils without termites from 6 to 111 . The $\mathrm{HCl}$ extracts also differ from each other in the $\mathrm{Sr} / \mathrm{Ca}$ ratio of the two types of samples: those from termite mounds range from 6 to $151 \times 10^{-3}$ and those from soils without termites from 8 to $1537 \times 10^{-3}$. As a consequence of the termite activity, the $\mathrm{HCl}$ leachates are enriched in all elements except $\mathrm{Al}$, which is found to be depleted in the mounds of the pairs 3 and 4, Ti and $\mathrm{Na}$ being depleted in the mound of pair 1 and Ti in the mound of pair 3. The $\mathrm{HCl}$ extracts also differ clearly in the total lanthanide concentrations and in the magnitude of the Ce anomaly among the sample pairs. Those from termite mounds have total concentrations of 16 to $366 \mu \mathrm{g} / \mathrm{g}$ of soil. The distribution of the data from termite mounds normalized to the PAAS reference have patterns with apparent enrichments in the middle lanthanides accompanied by negative $\mathrm{Ce}$ anomalies from 0.004 to 0.31 for the mounds 1 and 2 and a positive Ce anomaly of 1.54 in the mound 3. A small but significant $\mathrm{Eu}$ anomaly of 1.22 is seen for the sample from mound 3 , the other Eu anomalies being not significant due to analytical uncertainty (Fig. 3). The $\mathrm{HCl}$ extracts from soils without termites yield total concentrations of lanthanides of 0.69 to $687 \mu \mathrm{g} / \mathrm{g}$ (Table 5). The distribution patterns are also characterized by enrichments in the middle lanthanides with a negative Ce anomaly in the soils with termites of the sample pairs 1 and 2, a positive Ce anomaly of 1.22 and 3.61 in the same soils of the sample pairs 3 and 4, and a significant positive Eu anomaly of 1.25 in the same soil of the pair 3 (Fig. 3).

Termite activity apparently produced a consistent pattern of decreases in Si concentration and increases in $\mathrm{Al}, \mathrm{Ti}, \mathrm{Ca}, \mathrm{K}, \mathrm{Rb}$, and $\mathrm{Sr}$ concentrations in the soil materials. This systematic Si mobility has already been reported in studies on the lateritization process widely described in tropical soils, leaving Fe- and Alhydroxides behind (e.g., Millot, 1964), under a condition of high soil alkalinity. Timofeev (1987) suggested that this high alkalinity primarily makes $\mathrm{P}$ available to termites and other living beings. Breznak and Brune (1994), Brune et al. (1995) and Brune and Kuhl (1996) further suggested that high $\mathrm{pHs}$ help termites to digest soil bacteria and to solubilize the polyphenolic compounds. 
Lanthanides

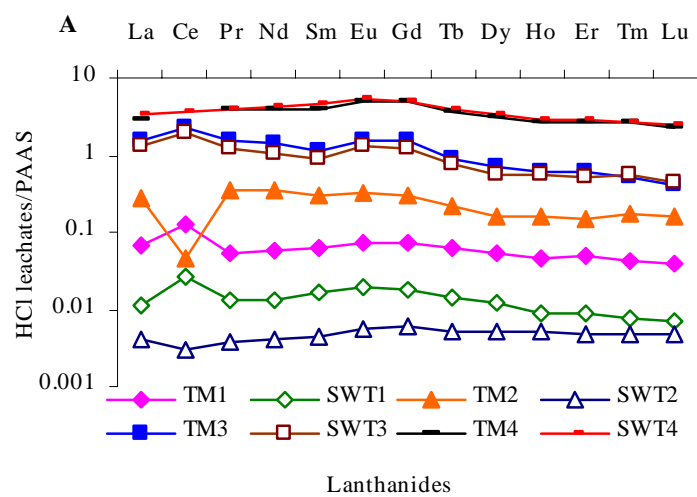

B La Ce Pr Nd Sm Eu Gd Tb Dy Ho Er Tm Yb Lu

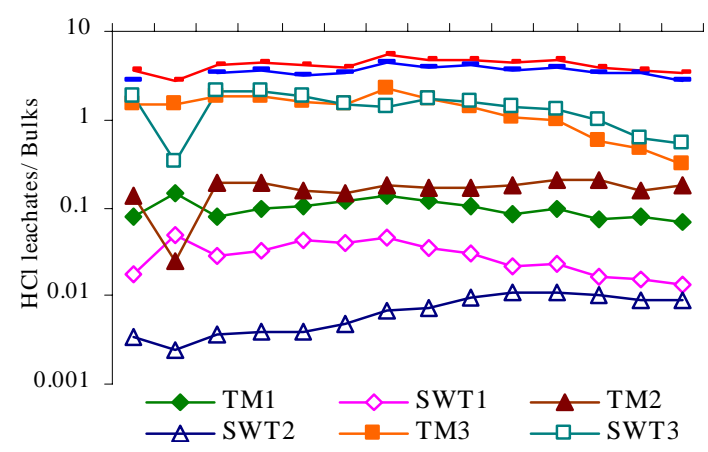

Fig. 3: Concentrations in lanthanides of the $\mathrm{HCl}$ leachates from termite mounds normalized (A) to the lanthanide pattern of the PAAS, and (B) to the lanthanide patterns in the corresponding mounds and soils called bulks. TM stands for termite mounds and SWT for soils without termites.

A potential cause for much of the elemental changes in soils hosting active termites is the relocation of many organic constituents from decomposed organic matter into framework minerals of the soils aided by the associated living system. Such relocations involve either nucleation and growth of new phases, or surface adsorption by termite modified minerals, or both. This is illustrated by the fact that the $\mathrm{H}_{2} \mathrm{O}$ and $\mathrm{HCl}$ leachates of materials from termite mounds and corresponding soils without termites substantially differ from each other in their chemical characteristics. Termite activity reorganized Ca from soils to form part of the water and acid-soluble phases, possibly some poorly crystalline Ca-Mg carbonate phases and Ca-bearing phosphates.

Although part of the Mn increase observed in the $\mathrm{HCl}$ leachates may relate to precipitation of a carbonate phase, at least some of it may be linked to Fe oxyhydroxides or Mn hydroxides. Birnessite or cryptomelane, for instance, are also known to accommodate some K (Lu et al., 2003; Rives et al., 2004), which could account for the accompanying $\mathrm{K}$ increase that is observed in the $\mathrm{HCl}$ leachates. In fact, relocation of elements as a result of termite activity is most clearly evident in the changing contents of the trace elements and in the $\mathrm{K} / \mathrm{Rb}$ ratio. While the mounds and corresponding soils differ little in their $\mathrm{K} / \mathrm{Rb}$ ratios, the $\mathrm{HCl}$ leachates from the same samples are significantly different in their $\mathrm{K} / \mathrm{Rb}$ ratios. It might be added that the $\mathrm{K} / \mathrm{Rb}$ values obtained for the mounds and soils are typical for common soil-forming silicate minerals (Chaudhuri et al., 2007). However, a relocation of $\mathrm{K}$ and $\mathrm{Rb}$ by an inorganic process alone, such as their reincorporation into newly-formed minerals after having been released during weathering of a primary mineral, does not explain the relatively high $\mathrm{K} / \mathrm{Rb}$ ratio of about 1040 for the $\mathrm{H}_{2} \mathrm{O}$ leachates from termite mounds. An intervention of a biochemical process is a potential explanation for the high $\mathrm{K} / \mathrm{Rb}$ ratio. The solubility of silicate minerals enhanced by termite activity might have contributed to the production of Si-bearing amorphous phases with susceptibility to dissolution by $\mathrm{H}_{2} \mathrm{O}$ and $\mathrm{HCl}$, which may account for their higher concentrations in such solvent extracts. The concomitant significant increases of $\mathrm{Al}, \mathrm{Mg}, \mathrm{Ca}$ and $\mathrm{P}$ in termite mounds, as recorded in the $\mathrm{H}_{2} \mathrm{O}$ and $\mathrm{HCl}$ leachates, are therefore responses to termite activity.

\section{The K-Ar tracing}

Among the $<2 \mu \mathrm{m}$ fractions of the three pairs of samples that were dated by the K-Ar method, that of one termite mound (pair 3) outlines a significant increase of $46.7 \%$ in the $\mathrm{K}$ content, while the $\mathrm{K}$ content of the same clay size fraction of another mound (pair 1) is enriched by $70.8 \%$, and that of the third mound size fraction (pair 4) decreases by about $10 \%$. Termite activity leads to an increase in the radiogenic ${ }^{40} \mathrm{Ar}$ content for the mound 3, and decreases in the mounds 1 and 4 . In all three cases that were investigated, termite activity leads to decreases in the K-Ar dates. Such decreases are generally explained by the effect of an alteration process, monitored mainly by the loss of radiogenic ${ }^{40} \mathrm{Ar}$ (e.g., Clauer and Chaudhuri, 1995). This explanation is not plainly applicable to this current study, as both loss and gain of radiogenic ${ }^{40} \mathrm{Ar}$ have been observed in the termite modified soil materials (Table 1). Basically, there must be a consistent reasoning for this, as it may be kept in mind that any K-Ar value, which results from ratio between the contents of $\mathrm{K}$ and 
its radiogenic ${ }^{40} \mathrm{Ar}$, integrates the individual apparent ages of all K-bearing soil particles. It may, therefore, be expected that soil clay particles are of diverse origin in terms of both, source and age. In other words, soil samples can certainly be regarded as heterogeneous material of varied provenance, with particles of different sizes and of varied types having different ${ }^{40} \mathrm{Ar}$ contents and $\mathrm{K}$ contents, which may explain the wide range of $\mathrm{K}-\mathrm{Ar}$ apparent ages obtained on the clay fractions of either the termite mounds or the soils without termites. Groups of minerals characterized by different trace element compositions could potentially have different degrees of susceptibility to alteration or weathering.

Even very subtle, these differences in the trace element compositions may play a significant role in the alteration/weathering of the particles and, therefore, between mineral particles and organic materials. Some of the trace elements could, for instance, represent necessary cofactors for enzyme activities of microorganisms. The need for such elements would compel the microorganisms to seek the elements from particles. This would lead to selective destruction of minerals in a mass of heterogeneous clay particles, consequently leading to either an enrichment or a release of either radiogenic ${ }^{40} \mathrm{Ar}$ or $\mathrm{K}$. The fact that gain of radiogenic ${ }^{40} \mathrm{Ar}$ in the clay fraction of one termite mound and loss in that of the two others draws a special attention towards the weathering process(es) involving clay minerals. In a broad view, weathering is seen as either a congruent or incongruent dissolution process.If the process is mainly congruent, the K-Ar apparent ages of the progressively altered/weathered K-bearing minerals should stay almost similar during the process as both isotopes are released concomitantly, which is not the case here, at least for two size fractions. In the case of a process dominated by an incongruent dissolution mode, the natural consequence is a decrease in the K-Ar data monitored by a preferential loss of radiogenic ${ }^{40} \mathrm{Ar}$ during the whole process (e.g., Clauer and Chaudhuri, 1995). Since this latter path is observed here in two out of the three studied sample pairs, it may be suggested that clay mineral alteration/weathering associated with termite activity is dominantly an incongruent dissolution process. Such a process of dissolution explains in turn, at least partly, the varied behaviour of the major and trace elements.

\section{The variations of the K/Rb and Sr/Ca ratios}

Whereas the bulk materials from termite mounds and from corresponding soils without termite activity differ little in their $\mathrm{K} / \mathrm{Rb}$ ratios, the $\mathrm{HCl}$ leachates from termite inhabited materials clearly differs from $\mathrm{HCl}$ leachates from soils without termite activity, the former having systematically higher $\mathrm{K} / \mathrm{Rb}$ ratios than the latter. The relative increase in the $\mathrm{K} / \mathrm{Rb}$ ratio for the materials in the mounds is of such a magnitude that it can be explained in terms of selective adsorption/absorption of $\mathrm{K}$ over $\mathrm{Rb}$ by newly-formed solid products. But this explanation cannot rule out the possibility that the relatively higher $\mathrm{K} / \mathrm{Rb}$ ratio for the mound materials arose at least in part as a consequence of the availability of these elements from plant materials that are being decomposed through termite activity. This may be suggested by the fact that water-soluble fractions from the materials of mounds have $\mathrm{K} / \mathrm{Rb}$ ratios as high as 1040. Such a high ratio is common for plant materials and generally uncommon for common K-bearing silicate minerals (Chaudhuri et al., 2007).

In summary, the main source for $\mathrm{K}$ and $\mathrm{Rb}$ of the dissolved phases in the $\mathrm{HCl}$ and $\mathrm{H}_{2} \mathrm{O}$ leachates is not only the components of the clay-particle interlayer sites, even if the weathering of the micatype components is incongruent as shown by the $\mathrm{K}$-Ar data, but also the immobilized nutrients in the termites or in plants that termites bury in their mounds. However, as $\mathrm{Rb}$ is held more tightly than $\mathrm{K}$ in the interlayer sites of clay minerals, the $\mathrm{K} / \mathrm{Rb}$ ratio of precipitated phases from a soil solution will be higher than the ratio of the same elements in the interlayer exchangeable position at equilibrium in $\mathrm{K}$ bearing clay particles. The difference between $\mathrm{K} / \mathrm{Rb}$ ratios of the $\mathrm{HCl}$ and $\mathrm{H}_{2} \mathrm{O}$ leachates termite mounds and from soils without termites, could mainly be due to differences between the amounts of $\mathrm{K}$ and $\mathrm{Rb}$ released from both and it may reflect the modifications in the soil structure, as Jouquet et al. (2002) reported that termites can modify the mineralogical properties of some clays. Greatest differences in the $\mathrm{Sr} / \mathrm{Ca}$ ratio were observed between the termite mounds and the soils without termites. Alternatively, the clay fractions and the corresponding termite mounds have nearly identical $\mathrm{Sr} / \mathrm{Ca}$ ratios, these ratios being about $1 / 5$ to $1 / 8$ of the clay fractions and the corresponding soils without termites. 
The termite activity apparently induced precipitation of $\mathrm{H}_{2} \mathrm{O}$ and $\mathrm{HCl}$ extractable phase(s) having low $\mathrm{Sr} / \mathrm{Ca}$ ratios. These phases could be amorphous or poorly crystalline Ca-phosphate or carbonate materials with low $\mathrm{Sr}$ contents, as evidenced by the extracts having middle lanthanide enrichments that are known to be associated with Ca-phosphate minerals. Since there is a correlation between the contents of $\mathrm{Ca}$ and $\mathrm{P}$ in the sample pairs 3 and 4, as well as in their $\mathrm{H}_{2} \mathrm{O}$ and $\mathrm{HCl}$ leachates, the increase of $\mathrm{P}$ and $\mathrm{Ca}$ could be due to a precipitation of a phosphate phase related to termite activity. In the sample pairs 3 and 4, where the content of $\mathrm{Ca}$ is much higher in the termite mounds than in the soil without termites, the increase of $\mathrm{Ca}$ in the $\mathrm{H}_{2} \mathrm{O}$ and $\mathrm{HCl}$ leachates may witness an important precipitation of carbonate phases compared to phosphate phases.

\section{The behaviour of the lanthanides}

Apparently, the termite activity induced an increase in the total concentration of lanthanides in all but one mound samples and in all but one $\mathrm{HCl}$ leachates. What should be noted here is that the lanthanide distribution patterns for the mound samples, relative to their corresponding soils without termite activity, are varied (Fig. 3). A concave upward distribution pattern, with middle lanthanide depletion, displayed by the mound 3 is an indication that termite activity resulted in products with potential removal of phosphate-bearing phase(s), which are commonly known for their middle lanthanide enrichment. The presence of a $\mathrm{Gd}$ negative anomaly in relation to this particular mound sample (mound 3) is somewhat striking. Discount the possibility of any analytical error, in view of the fact that have observed Gd anomalies in several of studies which is involved plant material analyses. Therefore the Gd negative anomaly may in part reflect involvement of plant material lanthanides assimilated during chemical reorganization of soil minerals modified by termite activity. A second variation in the lanthanide distribution was recorded by both mound samples 2 and 4, each marked by a flat lanthanide distribution pattern with a negative $\mathrm{Eu}$ anomaly. This general lack of any fractionation among the lanthanides due to termite activity may imply that either the lanthanides were complexed by sulphate-bearing ligands or the lanthanides were mostly immobile rendering a very little loss of the lanthanide elements during modification of soil materials by termite activity. The Eu anomaly may suggest a variety of factors that might have come into play.

These include the influence of redox reaction since $\mathrm{Eu}$ is known to have both trivalent and divalent states, the influence of feldspar minerals which are known to have structural preference for divalent $\mathrm{Eu}$

Table 4: Chemical composition of the $\mathrm{H}_{2} \mathrm{O}$ extracts

\begin{tabular}{|c|c|c|c|c|c|c|c|c|}
\hline \multirow[t]{2}{*}{ Elements $^{*}$} & \multicolumn{2}{|c|}{ Sample pair 1} & \multicolumn{2}{|c|}{ Sample pair 2} & \multicolumn{2}{|c|}{ Sample pair 3} & \multicolumn{2}{|c|}{ Sample pair 4} \\
\hline & TM & SWT & TM & SWT & $\mathrm{TM}$ & SWT & TM & SWT \\
\hline $\mathrm{Si}$ & 74.7 & 17.6 & 346.0 & 8.47 & 14.3 & 15.0 & 26.7 & 5.59 \\
\hline $\mathrm{Mg}$ & 74.9 & 3.17 & 1320 & 4.69 & 4.68 & 1.31 & 0.44 & 0.47 \\
\hline $\mathrm{Ca}$ & 164.9 & 2.93 & 3447 & 13.8 & 10.2 & 3.62 & 2.95 & 2.03 \\
\hline $\mathrm{Fe}$ & 60.5 & 6.08 & 115.2 & 7.67 & 0.69 & 4.39 & 15.7 & 0.76 \\
\hline $\mathrm{Na}$ & bdl & 0.41 & 483.0 & 3.43 & 2.11 & 1.15 & 2.26 & 0.74 \\
\hline $\mathrm{K}$ & 266.4 & 9.71 & 8295 & 19.1 & 78.9 & 5.93 & 21.0 & 13.2 \\
\hline $\mathrm{P}$ & ND & ND & 609.9 & 4.01 & 6.13 & 0.20 & 0.69 & 0.21 \\
\hline Total & 746.0 & 57.0 & 15055 & 70 & 119.1 & 45.0 & 90.7 & 25.0 \\
\hline $\mathrm{Rb}$ & 1452 & 60.3 & 28.0 & 0.16 & 0.08 & 0.04 & 0.09 & 0.10 \\
\hline
\end{tabular}

$\mathrm{TM}=$ termite mounds, $\mathrm{swt}=$ soils without termites, $\mathrm{ND}=$ Not Detected and $\mathrm{bdl}=$ below detection limit

"The concentrations are in $\mu \mathrm{g} / \mathrm{g}$ 
Int. J. Environ. Sci. Tech., 5 (4), 431-444, Autumn 2008

Table 5: Chemical composition of the $\mathrm{HCl}$ extracts

\begin{tabular}{|c|c|c|c|c|c|c|c|c|}
\hline \multirow[t]{2}{*}{ Elements $^{*}$} & \multicolumn{2}{|c|}{ Sample pair 1} & \multicolumn{2}{|c|}{ Sample pair 2} & \multicolumn{2}{|c|}{ Sample pair 3} & \multicolumn{2}{|c|}{ Sample pair 4} \\
\hline & TM & SWT & TM & SWT & TM & SWT & TM & SWT \\
\hline $\mathrm{Si}$ & 0.48 & 0.01 & 0.44 & 0.01 & 0.07 & 0.02 & 0.06 & 0.03 \\
\hline $\mathrm{Al}$ & 6.75 & 0.39 & 0.28 & 0.07 & 0.02 & 0.02 & 0.06 & 0.07 \\
\hline $\mathrm{Mg}$ & 25.5 & 0.02 & 15.8 & 0.01 & 0.26 & 0.04 & 0.09 & 0.02 \\
\hline $\mathrm{Ca}$ & 75.7 & 0.03 & 90.0 & 0.06 & 0.63 & 0.14 & 0.29 & 0.07 \\
\hline $\mathrm{Fe}$ & 7.36 & 0.15 & 2.63 & 0.63 & 0.06 & 0.02 & 0.18 & 0.11 \\
\hline $\mathrm{Mn}$ & 7.59 & 0.01 & 2.85 & 0.01 & 0.15 & 0.10 & 0.08 & 0.03 \\
\hline $\mathrm{Ti}$ & bdl & bdl & 0.01 & bdl & bdl & bdl & bdl & bdl \\
\hline $\mathrm{Na}$ & bdl & bdl & 0.47 & bdl & bdl & bdl & bdl & bdl \\
\hline $\mathrm{K}$ & 9.56 & 0.03 & 12.9 & 0.02 & 0.37 & 0.04 & 0.20 & 0.06 \\
\hline $\mathrm{P}$ & ND & ND & 3.85 & 0.21 & 0.02 & bdl & bdl & bdl \\
\hline Total & 133.0 & 0.64 & 129.2 & 1.02 & 1.58 & 0.38 & 0.96 & 0.38 \\
\hline $\mathrm{Rb}$ & 29.9 & 0.26 & 44.03 & 0.38 & 6.39 & 3.41 & 15.6 & 9.99 \\
\hline $\mathrm{Sr}$ & 797 & 0.38 & 562.12 & 0.47 & 94.5 & 25.7 & 34.7 & 110.4 \\
\hline $\mathrm{Cr}$ & 6.34 & 0.25 & bdl & 0.71 & bdl & bdl & bdl & bdl \\
\hline $\mathrm{Co}$ & 3.96 & 0.05 & 2.40 & 0.02 & 11.0 & 9.62 & 7.29 & 10.8 \\
\hline $\mathrm{Ni}$ & 0.00 & 0.24 & 4.96 & 0.09 & 2.82 & 0.62 & 1.33 & 1.21 \\
\hline $\mathrm{Cu}$ & 16.9 & 1.11 & 27.3 & 1.16 & 8.84 & 5.36 & 24.5 & 19.9 \\
\hline $\mathrm{Zn}$ & 76.1 & 1.49 & 168.9 & 0.70 & 8.94 & 2.10 & 6.22 & 3.87 \\
\hline $\mathrm{Rb}$ & 29.9 & 0.26 & 44.0 & 0.38 & 6.40 & 3.41 & 15.6 & 9.99 \\
\hline $\mathrm{Sr}$ & 797 & 0.38 & 562 & 0.47 & 94.5 & 25.7 & 34.7 & 110.4 \\
\hline $\mathrm{Zr}$ & & & 3.24 & 1.67 & 0.32 & 0.13 & 1.02 & 0.64 \\
\hline Mo & 0.01 & bdl & 0.21 & bdl & bdl & 0.04 & bdl & bdl \\
\hline $\mathrm{Cd}$ & 1.79 & 0.01 & 2.06 & 0.03 & 0.08 & 0.12 & 0.06 & 0.06 \\
\hline $\mathrm{Cs}$ & & & 0.32 & bdl & 0.01 & 0.05 & 0.26 & 0.61 \\
\hline $\mathrm{Ba}$ & 195 & 1.59 & 147.0 & 0.87 & 719 & 339 & 151.5 & 110.4 \\
\hline $\mathrm{Pb}$ & 7.10 & 0.68 & 3.36 & 0.05 & 16.9 & 21.8 & 33.9 & 38.2 \\
\hline Th & 1.26 & 0.09 & 0.04 & 0.02 & 0.13 & 0.13 & 0.94 & 0.57 \\
\hline $\mathrm{U}$ & 0.38 & 0.09 & 0.16 & 0.12 & 0.61 & 0.61 & 5.78 & 5.13 \\
\hline $\mathrm{Sr} / \mathrm{Ca}\left(10^{-3}\right)$ & 11 & 13 & 6 & 8 & 151 & 179 & 120 & 1537 \\
\hline $\mathrm{K} / \mathrm{Rb}$ & 320 & 111 & 293 & 61 & 58 & 10 & 13 & 6 \\
\hline $\mathrm{U} / \mathrm{Th}$ & 0.30 & 0.99 & 4.18 & 5.31 & 4.61 & 4.72 & 6.13 & 9.95 \\
\hline $\mathrm{La}$ & 2.55 & 0.42 & 10.7 & 0.15 & 61.0 & 49.6 & 113.9 & 126.9 \\
\hline $\mathrm{Ce}$ & 9.77 & 2.04 & 3.53 & 0.25 & 175.6 & 156.9 & bdl & 289.1 \\
\hline $\operatorname{Pr}$ & 0.48 & 0.11 & 3.20 & 0.03 & 13.5 & 10.6 & 33.3 & 35.7 \\
\hline $\mathrm{Nd}$ & 1.93 & 0.44 & 11.9 & 0.14 & 48.1 & 36.5 & 131.8 & 142.1 \\
\hline $\mathrm{Sm}$ & 0.36 & 0.09 & 1.68 & 0.03 & 6.02 & 4.81 & 22.4 & 25.1 \\
\hline $\mathrm{Eu}$ & 0.08 & 0.02 & 0.34 & 0.01 & 1.72 & 1.39 & 5.24 & 5.69 \\
\hline $\mathrm{Gd}$ & 0.35 & 0.09 & 1.34 & 0.03 & 6.92 & 5.50 & 22.7 & 23.6 \\
\hline $\mathrm{Tb}$ & 0.05 & 0.01 & 0.16 & bdl & 0.69 & 0.58 & 2.71 & 3.01 \\
\hline Dy & 0.25 & 0.06 & 0.74 & 0.02 & 3.42 & 2.69 & 14.6 & 15.6 \\
\hline Ho & 0.04 & 0.01 & 0.15 & 0.01 & 0.59 & 0.54 & 2.63 & 2.86 \\
\hline $\mathrm{Er}$ & 0.14 & 0.03 & 0.43 & 0.01 & 1.74 & 1.51 & 7.56 & 8.31 \\
\hline $\mathrm{Tm}$ & 0.02 & 0.00 & 0.07 & bdl & 0.21 & 0.22 & 1.05 & 1.10 \\
\hline $\mathrm{Yb}$ & 0.12 & 0.02 & 0.34 & 0.01 & 1.26 & 1.08 & 6.86 & 7.06 \\
\hline $\mathrm{Lu}$ & 0.02 & 0.00 & 0.07 & bdl & 0.17 & 0.19 & 0.97 & 1.08 \\
\hline Total & 16.2 & 3.34 & 34.7 & 0.69 & 320.9 & 272.2 & 365.7 & 687.2 \\
\hline $\mathrm{Ce} / \mathrm{Ce}^{*}$ & 0.06 & 0.01 & 0.31 & 0.004 & 1.54 & 1.22 & ND & 3.61 \\
\hline $\mathrm{Eu} / \mathrm{Eu}^{*}$ & 1.08 & 1.11 & 1.08 & 1.06 & 1.24 & 1.25 & 1.09 & 1.10 \\
\hline
\end{tabular}

$\mathrm{TM}=$ termite mounds, $\mathrm{swt}=$ soils without termites, $\mathrm{bdl}=$ below detection limit and ND $=$ Not Detectable

"The concentrations are in $\mathrm{mg} / \mathrm{g}$ for the major elements, in $\mu \mathrm{g} / \mathrm{g}$ for the trace elements and the lanthanides

over trivalent Eu because of the close similarity in the ionic radius between the divalent Eu and $\mathrm{Ca}$ ions, and the influence of preferential transport of Eu involved in enzyme activated reactions. The influence of redox reaction may not have been very significant, as no correlation became evident between Fe depletion or Mn depletion and Eu depletion. The influence of feldspar may not be strongly argued 
because the presence of any feldspar has not been directly observed, although the soils are known to contain a significant amount of kaolinite mineral which is often known to be a product of weathering of feldspar mineral. A third lanthanide distribution pattern is marked by light lanthanide enrichment. This may be explained in terms of preferential increased mobility of heavy lanthanides aided by high stability of these lanthanides building complexes with common organic ligands such as acetates, oxalates, malates etc., or with common inorganic ions such as bicarbonate and carbonate ions. The presence of Ce anomaly within the distribution patterns of lanthanides may be explained in terms of the presence of minor amounts of oxides and hydroxides of $\mathrm{Mn}$ and $\mathrm{Fe}$, which are known to incorporate preferentially Ce over other neighbouring lanthanides.

\section{The variations of the $U$ and Th concentrations}

As for most elements, the $U$ and Th concentrations increased in the termite mounds. The increase for Th is relatively higher than that for $\mathrm{U}$. In the $\mathrm{HCl}$ leachates, the decrease in the $U$ and $T h$ concentrations occurs in all mounds, except in that of the sample pair 3. As for the bulk samples, the U/Th ratios of the $\mathrm{HCl}$ leachates from termite mounds are lower than those of the $\mathrm{HCl}$ leachates from soils without termites. The increase in the $\mathrm{U}$ and $\mathrm{Th}$ concentrations in the mounds could be due to the incorporation of more $\mathrm{U}$ and $\mathrm{Th}$ in the newlyformed phases dissolved in $\mathrm{HCl}$, relative to the soils without termites.

With the exception of the mound 2, the U/Th ratios of the soils without termites and the $\mathrm{HCl}$ leachates in the termite mounds were found to be higher than those of the soils and $\mathrm{HCl}$ leachates without termites. The decrease in these ratios because of a termite activity could be due to a fractionation effect during incorporation of $U$ and $T h$ in the newly-formed phases dissolved by $\mathrm{HCl}$ leaching. In presence of termites, some chelating agent could be more abundant than in the soil without termites, and make diffusion as a dominated mechanism for the incorporation of $U$ and $\mathrm{Th}$ in the new phases in presence of termites.

\section{CONCLUSION}

This study showed that activity of termites induced significant chemical changes in the materials that they use to build their nests, increasing the contents of most major elements, as well as of $U$ and $T h$, relative to the soils with no visible termite activity, except $\mathrm{Si}$ and to a lesser extent $\mathrm{Fe}, \mathrm{Mn}, \mathrm{Na}$ and $\mathrm{K}$. A potential cause for such increases is the relocation of these elements into newly-formed $\mathrm{H}_{2} \mathrm{O}$ and $\mathrm{HCl}$ leachable minerals. KAr results suggest an incongruent weathering of the clay material due to biological activity, explaining, at least partly, the varied behaviour of the major and trace elements. $\mathrm{Ca}$ and $\mathrm{Mg}$ dissolved in the two types of leachates whiteness for crystallization of $\mathrm{Ca}-\mathrm{Mg}$ carbonate phases, part of the Mn probably relating to precipitation of a carbonate phase, and most to precipitation of $\mathrm{Fe}$ oxy-hydroxides and/or $\mathrm{Mn}$ hydroxides. Termite activity also induced precipitation of $\mathrm{H}_{2} \mathrm{O}$ and $\mathrm{HCl}$ extractable phase(s) having low $\mathrm{Sr} / \mathrm{Ca}$ ratios. These phases seem to be amorphous or poorly crystalline Ca-phosphates or carbonates, as evidenced by middle lanthanide enrichments that are known to be associated with Ca-phosphates. Even if the $\mathrm{K} / \mathrm{Rb}$ values of the termite mounds are typical for common soil-forming silicate minerals, their relocation by an inorganic process alone does not explain an abnormally high ratio in the $\mathrm{H}_{2} \mathrm{O}$ leachable mineral phases. It was also shown that the main source for $\mathrm{K}$ and $\mathrm{Rb}$ of the dissolved phases is not only the interlayer site of clay particles, but also nutrients immobilized in and by the termites. The termite mounds are especially enriched in light lanthanides relative to the corresponding soils without termites. The changing patterns support the precipitation of newly-formed mineral phases dissolved by dilute $\mathrm{HCl}$ and point to $\mathrm{Mn}-\mathrm{Fe}$ oxy-hydroxides and $\mathrm{Ca}$ carbonatesphosphates. A mechanism by which increased amounts of $\mathrm{Eu}$ and $\mathrm{Ce}$ are linked to termite activity seems to relate to the occurrence of some reducing agent or agents that are released by the termites, causing reduction of $\mathrm{Eu}^{3+}$ to $\mathrm{Eu}^{2+}$ and $\mathrm{Ce}^{4+}$ to $\mathrm{Ce}^{3+}$ in a chelate, favouring in turn some selective incorporation of $\mathrm{Eu}^{2+}$ and $\mathrm{Ce}^{3+}$ in the new phases of termite modified soils.

The concentrations and patterns of lanthanides, and the $\mathrm{K} / \mathrm{Rb}, \mathrm{U} / \mathrm{Th}$ and $\mathrm{Sr} / \mathrm{Ca}$ ratios appear to be useful tools for studies of changes in soil chemical compositions. The studies of trace elements such as the lanthanides can also lead to increased understanding of dissolution/precipitation of phases produced by organic activity, and the consequent mobility of the released elements from 
soils to ground- and surface waters. K-Ar isotopic dating appears also to be an appropriate tool to identify the dissolution processes of minerals.

\section{ACKNOWLEDGMENTS}

The authors would like to thank sincerely J. Samuel, R. Rouault, J. Balouka, R. Wendling and P. Larqué of the Centre de Géochimie de la Surface (CNRS-ULP) for technical assistance during this study.

\section{REFERENCES}

Akamigbo, F., (1984). The role of the nasute termites in the genesis and fertility of Nigerian soils. Pedologie, 34 (2), 179-189.

Breznak, J. A.; Brune, A., (1994). Role of microorganisms in the digestion of lignocellulose by termites. Ann. Rev. Entomol., 39, 453-487.

Briese, D. T., (1982). The effect of ants on the soil of a semi-arid saltbush habitat. Les effets des Fourmis sur le sol d'un habitat salé semi-aride à végétation buissonnante. Insect. Soc., 29 (2), 375-382.

Brossard, M.; Lopez-Hernandez, D.; Lepage, M.; Leprun, J. C., (2007). Nutrient storage in soils and nests of moundbuilding Trinervitermes termites in Central Burkina Faso: consequences for soil fertility. Biol. Fert. Soils, 43 (4), 437-447.

Brune, A.; Kuhl, M., (1996). pH profiles of the extremely alkaline hind guts of soil - feeding termites (isoptera: Termitidae) determined with microelectrodes. J. Insect. Physiol., 42 (11), 1121-1127.

Brune, A.; Emerson, D.; Breznak, J. A., (1995). The termite gut microflora as an oxygen sink: Microelectrode determination of oxygen and $\mathrm{pH}$ gradients in guts of lower and higher termites. Appl. Environ. Microb., 61 (7), 26812687.

Chao, T. T.; Zhou, L., (1983). Extraction techniques for elective dissolution of amorphous ion oxides from soils and sediments. Soil Sci. Soc. Am. J., 47 (2), 225-232.

Chaudhuri, S.; Clauer, N.; Semhi, K., (2007). Plant decay as a major control of river dissolved potassium: A first estimate. Chem. Geo., 243 (1-2), 178-190.

Clauer, N.; Chaudhuri, S., (1995). Clays in crustal environments, isotope dating and tracing. Springer Verlag, Heidelberg, Berlin, 359.

Donovan, S. E.; Eggleton, P.; Dubbin, W. E.; Batchelder, M.; Dibog, L., (2001). The effect of a soil feeding termite, Cubitermes fungifaber (Isoptera: Termitidae) on soil properties: Termites may be an important source of soil microhabitat heterogeneity in tropical forests. Pedobiologia, 45 (1), 1-11.

Heikens, A.; Peijenburg, W. J. G. M.; Hendriks, A. J., (2001). Bioaccumulation of heavy metals in terrestrial invertebrates. Environ. Pollut., 113 (3), 385-393.

Howse, P. E., (1970). Termites: A study in social behaviour. Hutchinson University Library, London, 150.

Jouquet, P.; Mamou, L.; Lepage, M.; Velde, B., (2002). Effect of termites on clay minerals in tropical soils; fungus-growing termites as weathering agents. Eur. J. Soil Sci., 53 (4), 521-527.
Jouquet, P.; Tessier, D.; Lepage, M., (2004). The soil structural stability of termite nests: role of clays in Macrotermes bellicosus (Isoptera, Macrotermitinae) mound soils. Eur. J. Soil Biol., 40 (1), 23-29.

Jungerius, P. D.; Van Den Ancker, J. A. M.; Mücher, H. J., (1999). The contribution of termites to the microgranular structure of soils on the Uasin Gishu Plateau, Kenya. Catena, 34 (3), 349-363.

Lobry De Bruyn, L. A.; Conacher, A. J., (1990). The role of termites and ants in soil modification: A review. Aust. J. Res., 28 (1), 55-93.

Lopez-Hernandez, D.; Brossard, M.; Fardeau, J. C.; Lepage, M., (2006). Effect of different termite feeding groups on $\mathrm{P}$ sorption and $\mathrm{P}$ availability in African and south American savannas. Biol. Fert. Soils, 42 (3), 207-214.

Lu, A.; Gao, X.; Qin, S.; Wang, C., (2003). Cryptomelane (KxMn8-xO16): Natural active octahedral molecular sieve (OMS-2). Chinese Sci. Bull., 48 (9), 920-923.

Mahaney, W. C; Zippin, J.; Milner, M. W.; Sanmugadas, K.; Kancock, R. G. V.; Aufreiter, S., (1999). Chemistry, mineralogy and microbiology of termite mound soil eaten by champanzees of the Mahal mountains, Western Tanzania. J. Trop. Ecol., 15 (5), 565-588

Mando, A.; Stroosnijder, L.; Brussard, L., (1996). Effects of termites on infiltration into crusted soil. Geoderma, 74 (12), 107-113.

McLennan, S., (1989). Rare earth elements in sedimentary rocks: influence of provenance and sedimentary processes. In: Geochemistry and mineralogy of rare earth elements. In: B. Lipin and G. McKay (Eds.). Mineralogical Society of America. Rev. Mineral. Geochem., 21 (1), 169-200.

Millot, G., (1964). Géologie des Argiles-Altérations, Sédimentologie, Géochimie. Masson et Cie, Paris, 499.

Ndam Ngoupayou, J. R., (1997). Bilans hydrogéochimiques sous forêt tropicale humide en Afrique: du bassin expérimental de Nsimi-Zoétélé aux réseaux hydrographiques du Nyong et de la Sanaga au Sud-Cameroun. $\mathrm{PhD}$ thesis University Pierre et Marie Curie, Paris VI.

Ndiaye, D.; Lepage, M.; Sall Cire, E.; Brauman, A., (2004). Nitrogen transformations associated with termite biogenic structures in a dry savanna ecosystem. Plant. Soils, 265 (1-2), 189-196.

Noirot, C., (1970). The nest of termites, In: K. Krishna and F.M. Weesner (Eds.), Biology of termites. Academic Press, New York. Vol. 2, 73-125.

Nye, P. H., (1955). Some soil-forming processes in the humid tropics, the action of the soil fauna. J. Soil Sci., 6 (1), 73 83.

Pomeroy, D. E., (1976). Some effects of mound building termites on soils in Uganda. J. Soil Sci., 27 (3), 377-394

Rives, V.; Del Arco, M.; Prieto, O., (2004). Birnessites prepared by ion exchange. Structural evolution with temperature. Boll. Soc. Esp. de Cer. y Vid., 43 (2), 142147.

Roose Amsaleg, C.; Brygoo, Y.; Harry, M., (2004). Ascomycete diversity in soil-feeding termite nests and soils from a tropical rainforest. Environ. Microbiol., 6 (5), 462469.

Samuel, J.; Rouault, R.; Besnus, Y., (1985). Analyse multiélémentaire standardisée des matériaux géologiques en spectrométrie d'émission par plasma à couplage inductif. Analysis, 13 (7), 312-317. 


\section{K. Semhi et al.}

Sys, C., (1955). The importance of termites in the formation of Latosols in the region of Elizabethville. Sols Africains, 3, 392-395.

Timofeev, B. V., (1987). A biological factor in tropical pedogenesis. Moscow U. Soil Bull., 42 (1), 70-72.

Vandecasteele, B.; Samyn, J.; Quataert, P.; Muys, B.; Tack, F.

M. G., (2004). Earthworm biomass as additional information

for risk assessment of heavy metal biomagnification: a case study for dredged sediment-derived soils and polluted floodplain soils. Environ. Pollut., 129 (3), 363-375.

Wood, T. G., (1988). Termites and the soil environment. Biol. Fert. Soils, 6 (3), 228-236.

\section{AUTHOR (S) BIOSKETCHES}

Semhi, K., Ph.D., Former associate researcher of the Centre de Géochimie de la Surface, Université Louis Pasteur, 1 rue Blessig, 67084 Strasbourg, France. Email: semkhad@yahoo.fr

Chaudhuri, S., Ph.D., Professor at the Department of Geology, Kansas State University, Manhattan, Kansas 66506, USA. Email: sambhuc@earthlink.com

Clauer, N., Ph.D., Emeritus Research Director of the Centre National de la Recherche Scientifique, at the Centre de Géochimie de la Surface, Université Louis Pasteur, 1 rue Blessig, 67084 Strasbourg, France. Email: nclauer@illite.u-strasbg.fr

Boeglin, J. L., Ph.D., Researcher of the Institut de la Recherche pour le Développement, at the Laboratoire des Mécanismes et Transferts en Géologie, Université Paul Sabatier, 14 Avenue E. Belin, 31400 Toulouse, France. Email: boeglin@lmtg.obs-mip.fr

\section{This article should be referenced as follows:}

Semhi, K.; Chaudhuri, S.; Clauer, N.; Boeglin, J. L., (2008). Impact of termite activity on soil environment: A perspective from their soluble chemical components. Int. J. Environ. Sci. Tech., 5 (4), 431-444. 